\title{
PENGARUH LABA KOTOR DAN ARUS KAS OPERASI TERHADAP RETURN SAHAM
}

Oleh :

\author{
Indira Shinta Dewi.,SE.,MM,AK \\ Fakultas Ekonomi Program Studi Akuntansi \\ Universitas Satya Negara Indonesia
}

\begin{abstract}
ABSTRAK
Laba kotor adalah selisih pendapatan perusahaan dikurangi dengan biaya barang terjual. Semua biaya-biaya langsung yang berhubungan dengan penciptaan produk dikelompokkan sebagai biaya barang terjual. Jika arus kas menghasilkan kenaikan kas, berarti investor melihat adanya kas masuk sehingga investor tertarik untuk melakukan pembelian saham perusahaan karena investor melihat adanya kinerja perusahaan yang baik dalam pengelolaan kas untuk meningkatkan kas masuk masa depan.

Peneliti sebelumnya Febrianto (2005) membuktikan angka laba kotor lebih mampu memberikan gambaran yang lebih baik mengenai hubungan antara laba dengan harga saham dibandingkan dengan laba bersih dan laba operasi. Resta (2012) membuktikan bahwa arus kas operasi berpengaruh positif dan signifikan terhadap return saham.

Tujuan penelitian ini adalah untuk mengetahui pengaruh laba kotor dan arus kas operasi terhadap return saham pada perusahaan manufaktur yang terdaftar di Bursa Efefk Indonesia tahun 2012-2014. Dalam sampel penelitian ini menggunakan teknil purposive sampling. Berdasrkan kriteria diperoleh sampel observasi sebanak 35 perusahaan. Data dan metode dalam pengumpulan data yang digunakan adalah data sekunder yang bersumber dari laporan keuangan perusahaan. Menggunakan analisis regresi linier berganda untuk menganalisis data. Dari hasil uji partial menunjukkan bahwa laba kotor dan arus kas operasi tidak berpengaruh terhadap return saham.
\end{abstract}

Kata Kunci: Laba Kotor, Arus Kas Operasi dan Return Saham 


\section{PENDAHULUAN}

PSAK NO 1 (IAI,2002) menyatakan bahwa laporan laba rugi harus memuat informasi laba kotor,laba operasi dan laba bersih. Laba kotor adalah selisih pendapatan perusahaan dikurangi dengan biaya barang terjual. Biaya barang terjual adalah semua biaya yang dikorbankan,untuk perusahaan manufaktur mulai dari tahap ketika bahan baku masuk pabrik,diolah dan hingga dijual. Semua biaya-biaya langsung yang berhubungan dengan penciptaan produk dikelompokkan sebagai biaya barang terjual. Bagi perusahaan dagang, biaya barang terjual ini akan terdiri dari biaya-biaya harga beli barang dan biaya lain yang dikeluarkan untuk menjadikan barang tersebut siap dijual.

Pada penelitian ini peneliti menggunakan laba kotor untuk melihat pengaruhnya terhadap return saham. Dasar pengambilan variabel laba kotor ini didasarkan atas hasil penelitian Triyono dan jogiyanto (1998) bahwa informasi laba kotor mempunyai kandungan informasi yang direaksi oleh investor dan mampu menggambarkan hubungan laba dengan return saham. Febrianto (2005) membuktikan angka laba kotor lebih mampu memberikan gambaran yang lebih baik mengenai hubungan antara laba dengan harga saham dibandingkan dengan laba bersih dan laba operasi. Febrianto juga menyatakan tidak ada bukti bahwa peneliti-peneliti yang lain memiliki dasar logika empirik dalam menggunakan variabel angka laba bersih dan operasi dan bukannya menggunakan angka laba kotor.

Penelitian Petrus (2010) membuktikan bahwa laba kotor tidak mempunyai pengaruh signifikan terhadap return saham, total arus kas mempunyai pengaruh signifikan terhadap return saham, size perusahaan mempunyai pengaruh yang abu-abu terhadap return saham.

Menurut Ninna ( 2006) penelitiannya membuktikan adanya pengaruh yang signifikan antara laba kotor, arus kas investasi terhadap expected return sedangkan arus kas aktivitas operasi tidak menunjukkan pengaruh yang signifikan terhadap expected return

Berdasarkan hasil penelitian dari peneliti terdahulu, peneliti membuat dugaan bahwa informasi laba kotor kemungkinan akan berpengaruh positif terhadap return saham. Jika suatu perusahaan menghasilkan laba yang semakin besar, maka perusahaan itu juga akan mampu memberikan deviden yang besar. Dengan meningkatnya dividen yang diterima oleh pemegang saham, maka return yang diterima oleh pemegang saham juga akan meningkat.

Selain informasi dari laba kotor, laporan arus kas menjadi laporan yang dianggap perlu disampaikan oleh perusahaan sebagai informasi kepada calon investor sejak IAI (1994) mengeluarkan PSAK No.2 tertanggal 7 September 1994 dan berlaku mulai 1 Januari 1995 yang merekomendasikan untuk memasukkan laporan arus kas sebagai bagian dari laporan keuangan. Keputusan BAPEPAM No. Kep. 80/PM/96, tertanggal 17 Januari 1996 juga menyatakan tentang kewajiban emiten menyertakan laporan arus kas (cash flow) dalam laporan keuangan berkala kepada Bapepam.

Hubungan arus kas dari kegiatan operasi dengan return saham dapat dijelaskan bahwa semakin tinggi arus kas operasional perusahaan maka semakin tinggi pula kepercayaan investor pada perusahaan tersebut, sehingga semakin besar pula nilai expected return saham. 
Dan sebaliknya, semakin rendah arus kas operasional perusahaan maka semakin kecil kepercayaan investor pada perusahaan tersebut, sehingga semakin kecil pula expected return saham yang akan diterima . maka ada hubungan positif antara arus kas operasi dengan return saham.

Meski setiap perusahaan sudah mengoptimalkan laba mereka, namun berdasarkan fakta yang terjadi pada kondisi riilnya terdapat ketidak konsistenan dengan teori yang ada. Bila laba meningkat maka return saham juga akan meningkat. Namun dalam penelitian ini ditemukan ketidak konsistenan teori dengan data yang ada, seperti dalam tabel berikut:

Tabel 1.1 Fenomena Penelitian Laba Kotor Dengan Return Saham

\begin{tabular}{|c|l|l|l|l|l|}
\hline $\begin{array}{l}\text { N } \\
\text { o }\end{array}$ & Nama Perusahaan & $\begin{array}{l}\text { Laba Kotor } \\
\text { Tahun 2012 }\end{array}$ & $\begin{array}{l}\text { Laba Kotor } \\
\text { Tahun 2013 }\end{array}$ & $\begin{array}{l}\text { Return } \\
\text { Saham } \\
2012\end{array}$ & $\begin{array}{l}\text { Return } \\
\text { Saham } \\
2013\end{array}$ \\
\hline 1 & $\begin{array}{l}\text { Semen Indonesia } \\
\text { (Persero) Tbk/SMGR }\end{array}$ & 9.297 .581 & 10.944 .094 & 0,20 & 0,11 \\
\hline 2 & $\begin{array}{l}\text { Keramika Indonesia } \\
\text { Assosiai Tbk / KIAS }\end{array}$ & 127.560 .000 & 171.088 .000 & 1,33 & 0,11 \\
\hline
\end{tabular}

Sumber: $\underline{w w w . i d x}$.

Tabel 1.2Fenomena Penelitian

Laporan Arus Kas Operasi Dengan Return Saham

\begin{tabular}{|c|l|l|l|l|l|}
\hline N & Perusahaan & $\begin{array}{l}\text { Laporan } \\
\text { Arus Kas } \\
\text { Operasi } \\
2012\end{array}$ & $\begin{array}{l}\text { Laporan } \\
\text { Arus Kas } \\
\text { Operasi } \\
2012\end{array}$ & $\begin{array}{l}\text { Return } \\
\text { Saham } \\
2012\end{array}$ & $\begin{array}{l}\text { Return } \\
\text { Saham } \\
2013\end{array}$ \\
\hline 1 & $\begin{array}{l}\text { Inti Keramik Alam } \\
\text { Asri Industri Tbk } \\
\text { /IKAI }\end{array}$ & $\begin{array}{l}77.476 .452 \\
12.113 .426\end{array}$ & 0,01 & 0,02 \\
\hline 2 & $\begin{array}{l}\text { Keramika Indonesia } \\
\text { Assosiai Tbk/KIAS }\end{array}$ & 131.131 .527 & 195.024 .561 & 1,33 & 0,11 \\
\hline
\end{tabular}

Sumber: $w w w \cdot i d x$.

Data yang terdapat pada tabel diatas merupakan perusahaan manufaktur yang tercatat di Bursa Efek Indonesia (BEI) . Pada table tersebut terlihat ketidakkonsistenan antara kondisi perusahaan dengan pernyataan yang telah dipaparkan sebelumnya bahwa jika laba kotor dan arus kas operasi meningkat maka return saham juga akan meningkat. Namun realnya tidak demikian laba kotor dan arus kas operasi meningkat tidak diikuti dengan meningkatnya return saham. Berdasarkan hasil pengamatan data tersebut memperkuat peneliti untuk melakukan penelitian ini. 
Beberapa penelitian terdahulu seperti Seno (2011) membuktikan bahwa arus kas operasi tidak berpengaruh terhadap return saham, laba akuntansi berpengaruh signifikan terhadap return saham

Resta (2012) membuktikan bahwa arus kas operasi berpengaruh positif dan signifikan terhadap return saham, arus kas investasi berpengaruh positif dan signifikan terhadap return saham, arus kas pendanaan tidak berpengaruh terhadap return saham.

Utomo (2011) meneliti pengaruh Arus Kas Operasi dan Laba Akuntansi Terhadap Return Saham . Hasil penelitiannya membuktikan bahwa laba akuntansi berpengaruh signifikan terhadap return saham, sedangkan variabel arus kas operasi secara parsial tidak berpengaruh terhadap return saham.

Tidak konsistennya hasil penelitian-penelitian tersebut menimbulkan research gap yang membutuhkan penelitian lebih lanjut, hal ini menarik bagi peneliti untuk melakukan pengujian kembali dengan judul penelitian " Pengaruh Laba Kotor dan Arus Kas Operasi Terhadap Return Saham Perusahaan Manufaktur di Bursa Efek Indonesia “.

\section{Perumusan masalah}

1. Apakah laba kotor berpengaruh terhadap return saham?

2. Apakah arus kas operasi berpengaruh terhadap return saham?

\section{Tujuan dan Manfaat Penelitian}

\section{Tujuan Penelitian}

1. Untuk mengetahui pengaruh laba kotor terhadap return saham

2. Untuk mengetahui pengaruh arus kas operasi terhadap return saham.

\section{Manfaat penelitian}

1. Bagi peneliti sebagai bentuk pembuktian aplikasi ilmu dan sebagai salah satu bentuk tridarma perguruan tinggi yang merupakan kewajiban untuk setiap dosen

2. Bagi aspek keilmuan, penelitian ini bisa dijadikan sebagai referensi bagi penelitian selanjutnya atau sebagai tambahan informasi dan wawasan.

\section{TINJAUAN PUSTAKA \\ Return Saham}

Return saham menurut Sundjaja (2010:43) adalah pertukaran antara pengembalian dan risiko (risk-return tradeoff) adalah harapan bahwa untuk menerima risiko yang lebih besar, dengan kompensasi pengembalian (return) yang lebih besar.

Pengembalian yang lebih tinggi sebagai biaya untuk penerbit diharapkan dengan risiko yang lebih besar. Manager keuangan harus mencoba untuk memperoleh pengembalian (return) yang tinggi dan biaya yang rendah, tetapi mereka juga harus mempertimbangkan risiko-risiko dari masing-masing investasi dan alternatif keuangan. Keputusan akhirnya tergantung pada analisa dari pengaruh risiko dan pengembalian (return) dari harga saham. 
Sikap investor terhadap risiko tentu akan sangat tergantung kepada preferensi investor tersebut terhadap risiko. Investor yang lebih berani akan memilih risiko investasi yang tinggi, yang diikuti oleh harapan tingkat return yang tinggi pula. Demikian pula sebaliknya, investor yang tidak mau menanggung risiko yang terlalu tinggi, tentunya tidak akan bisa mengharapkan tingkat return yang terlalu tinggi.

Pada dasarnya, ada dua keuntungan yang diperoleh investor dengan membeli atau memiliki saham, yaitu:

\section{Dividen}

Definisi dividen menurut (Darmadji, 2011:9) adalah "pembagian keuntungan yang diberikan perusahaan penerbit saham tersebut atas keuntungan yang dihasilkan perusahaan". Investor yang berhak menerima dividen adalah investor yang memegang saham hingga batas waktu yang ditentukan oleh perusahaan pada saat pengumuman dividen.

Dividen yang dibagikan perusahaan dapat berupa:

a. Dividen tunai, yaitu kepada setiap pemegang saham diberikan dividen berupa uang tunai dalam jumlah rupiah tertentu untuk setiap saham

b. Dividen saham, yaitu kepada setiap pemegang saham diberikan dividen sejumlah saham sehingga jumlah saham yang dimiliki seorang investor akan bertambah dengan adanya pembagian dividen saham tersebut.

\section{Capital gain}

Menurut (Darmadji, 2011:9), definisi Capital gain merupakan "selisih antara harga saham pada saat pembelian dengan harga saham pada saat penjualan." Capital gain terjadi jika harga saham pada akhir periode lebih tinggi dari harga awalnya.

Di samping dua keuntungan tersebut, maka pemegang saham juga dimungkinkan untuk mendapatkan Saham bonus (jika ada). Saham bonus merupakan saham yang dibagikan perusahaan kepada para pemegang saham yang diambil dari agio saham. Agio saham adalah selisih antara harga jual terhadap harga nominal saham tersebut pada saat perusahaan melakukan penawaran umum di pasar perdana.

\section{Jenis-Jenis Return Saham}

Menurut Jogiyanto (2009:199) Return merupakan "hasil yang diperoleh dari invetasi”. Return terdiri dari dua jenis, yaitu :

1. Return realisasian (realized return) merupakan return yang telah terjadi. Return realisasian dihitung menggunakan data historis. Return realisasian penting karena digunakan sebagai salah satu pengukur kinerja dari perusahaan. Return realisasian ini berguna sebagai dasar penentuan return ekspektasian (expected return) dan risiko di masa datang.

2. Return ekspektasian (expected return) adalah return yang diharapkan akan diperoleh oleh investor di masa mendatang. Berbeda dengan return realisasian yang sifatnya sudah terjadi, return ekspektasian sifatnya belum terjadi. 
Capital gain atau capital loss merupakan selisih dari harga investasi sekarang relatif dengan harga periode yang lalu (Jogiyanto, 2009:200)

Capital Gain atau Capital Loss $=$ Return saham $=\frac{P t-P t-1}{P_{t-1}}$

Keterangan :

$P_{t} \quad=$ Harga saham periode sekarang

$P_{t-1} \quad=$ Harga saham periode sebelumnya

\section{Risiko Saham}

Saham merupakan surat berharga yang memberikan peluang keuntungan tinggi namun juga berpotensi risiko tinggi. Saham memungkinkan investor untuk mendapatkan return atau keuntungan (capital gain) dalam jumlah besar dalam waktu singkat. (Darmadji, 2011:10)

Risiko investor yang memiliki saham, diantaranya:

\section{Tidak mendapat dividen}

Perusahaan akan membagikan dividen jika operasinya menghasilkan keuntungan. Sebaliknya, perusahaan tidak dapat membagikan dividen jika perusahaan tersebut mengalami kerugian.

\section{Capital loss}

Dalam aktivitas perdagangan saham, investor tidak selalu mendapatkan capital gain alias keuntungan atas saham yang dijualnya. Ada kalanya investor harus menjual saham dengan harga jual lebih rendah dari harga beli. Dengan demikian investor mengalami capital loss.

Risiko investor yang memiliki saham, diantaranya:

\section{Tidak mendapat dividen}

Perusahaan akan membagikan dividen jika operasinya menghasilkan keuntungan. Sebaliknya, perusahaan tidak dapat membagikan dividen jika perusahaan tersebut mengalami kerugian.

\section{Capital loss}

Dalam aktivitas perdagangan saham, investor tidak selalu mendapatkan capital gain alias keuntungan atas saham yang dijualnya. Ada kalanya investor harus menjual saham dengan harga jual lebih rendah dari harga beli. Dengan demikian investor mengalami capital loss.

\section{Laba Kotor/ Gross Profit}

Laba kotor adalah selisih dari pendapatan perusahaan dikurangi dengan harga pokok produksi. Harga pokok produksi adalah semua biaya yang dikorbankan, untuk perusahaan manufaktur biaya ini mulai dari tahap ketika bahan baku masuk ke pabrik, diolah, dan hingga dijual. Semua biaya-biaya langsung yang berhubungan dengan penciptaan produk tersebut dikelompokkan sebagai biaya produksi. Bagi perusahaan dagang, biaya ini terdiri dari biaya harga beli barang dan biaya lain yang dikeluarkan untuk menjadikan barang tersebut siap dijual. 
Angka laba kotor sebenarnya lebih terkendali oleh manajer dan memiliki hubungan yang lebih erat dengan penciptaan pendapatan (Febrianto 2005). Berdasarkan pernyataan Febrianto tersebut maka dapat dikaji lebih dalam dengan mengkaitkannya dengan masalah biaya barang terjual. Biaya barang terjual sepenuhnya terkendali oleh manajemen karena akan menentukan daya saing produk di pasar. Manajemen pasti berusaha untuk mengendalikan biaya tersebut pada tingkat yang rendah agar barang/jasa bisa dijual dengan harga yang kompetitif dan, dengan demikian, biaya ini memiliki hubungan langsung dengan penciptaan pendapatan. Rekening-rekening yang membentuk rekening biaya barang terjual pun relatif bebas dari pilihan metoda akuntansi misal masalah pembebanan biaya overhead pabrik yang sebenarnya tidak terlalu mengubah nilai akhir biaya barang terjual. Metoda ABC dan just-in-time, misalnya, adalah bukti bahwa manajemen berusaha keras untuk mengendalikan harga pokok produksi atau mengendalikan biaya barang terjual.

Dengan demikian, diduga bahwa laba kotor sebenarnya lebih operatif sifatnya dibandingkan dengan laba operasi. Komponen biaya-biaya pada rekening biaya barang terjual mampu diprediksi oleh manajer dan berhubungan langsung dengan penciptaan pendapatan

\section{Hubungan Laba Kotor Terhadap Return Saham}

Laba kotor dianggap berguna untuk tujuan pengendalian, terutama dalam melaporkan kepengurusan (penggunaan sumber daya yang dipercayakan kepada manajemen). Laba kotor menyampaikan sebagian latar belakang dari cerita tentang bagaimana cara manajemen memenuhi tanggung jawabnya. (Belkouli, 2012:231).

Semakin besar laba kotor yang diperoleh perusahaan maka semakin tinggi minat investor untuk berinvestasi di perusahaan tersebut karena investor beranggapan bahwa biaya barang terjual mampu diprediksi oleh manajer dan berhubungan langsung dengan penciptaan pendapatan, sehingga semakin besar pula nilai expected return saham. Dan sebaliknya, semakin kecil laba kotor yang diperoleh perusahaan maka semakin kecil minat investor untuk berinvestasi di perusahaan tersebut, sehingga semakin kecil pula nilai expected return saham.

\section{Arus Kas Operasi}

Definisi arus kas operasi menurut (Skousen, 2004:320) “Arus kas operasi adalah transaksitransaksi dan kejadian-kejadian yang akan menentukan laba bersih. Jumlah kas bersih yang diterima dari atau dikeluarkan untuk aktivitas operasi merupakan angka utama dalam laporan arus kas. Sama halnya dengan laba bersih yang digunakan untuk mengikhtisarkan segala sesuatu pada laporan laba rugi, kas bersih dari aktivitas operasi merupakan hal yang paling penting atau "bagian bawah (bottom line)" dari laporan arus kas.

Definisi menurut PSAK No. 2 tahun 2009 tentang aktifitas operasi adalah aktivitas operasi adalah aktivitas penghasil utama pendapatan perusahaan (principal reveue-producing activities) dan aktivitas lain yang bukan merupakan aktivitas investasi dan aktivitas pendanaan." 
Jumlah arus kas yang berasal dari aktivitas operasi merupakan indikator yang menentukan apakah operasi perusahaan dapat menghasilkan arus kas yang cukup untuk melunasi pinjaman, memelihara kemampuan operasi perusahaan, membayar deviden dan melakukan investasi baru tanpa mengandalkan sumber pendanaan dari luar.

Arus kas dari aktivitas operasi perusahaan diperoleh dari aktivitas penghasil utama pendapatan perusahaan. Oleh karena itu, arus kas tersebut pada umumnya berasal dari transaksi dan peristiwa lain yang memengaruhi penetapan laba atau rugi bersih.

Penerimaan kas dari penjualan barang atau pemberian jasa adalah arus kas masuk utama dalam bisnis. Jumlah kas bersih yang diterima dari atau dikeluarkan untuk aktivitas operasi merupakan angka utama dalam laporan arus kas.

Walaupun arus kas dari bunga atau deviden secara logis dapat diklasifikasikan sebagai aktivitas investasi atau pendanaan, namun FASB memutuskan untuk mengklasifikasikan keduanya sebagai aktivitas operasi. Prinsip dasarnya adalah karena "aktivitas operasi berisikan pengaruh arus kas dari pendapatan dan beban yang ada di laporan laba rugi" (Skousen 2004:321).

Arus kas dari aktivitas operasi umumnya disajikan terlebih dahulu, lalu diikuti dengan arus kas dari aktivitas investasi dan aktivitas pendanaan. Total arus kas bersih dari aktivitas tersebut merupakan kenaikan atau penurunan bersih kas, dan setelah itu saldo kas akhir periode dilaporkan.

\section{Hubungan Arus Kas Operasi Terhadap Return Saham}

Arus kas operasi (operating activities) meliputi kas yang dihasilkan dan dikeluarkan yang masuk dalam determinasi penentuan laba bersih arus kas dari aktivitas operasi merupakan indikator yang menentukan apakah dari operasinya perusahaan dapat menghasilkan kas yang dapat digunakan untuk melunasi pinjaman, memelihara kemampuan operasi perusahaan, membayar deviden dan melakukan investasi baru tanpa mengandalkan sumber pendanaan dari luar.

Semakin tinggi arus kas operasional perusahaan maka semakin tinggi pula kepercayaan investor pada perusahaan tersebut, sehingga semakin besar pula nilai expected return saham. Dan sebaliknya, semakin rendah arus kas operasional perusahaan maka semakin kecil kepercayaan investor pada perusahaan tersebut, sehingga semakin kecil pula expected return saham yang akan diterima.

\section{METODE PENELITIAN}

\section{Populasi dan Sampel}

Populasi yang digunakan dalam penelitian ini adalah perusahaan manufaktur yang terdaftar di Bursa Efek Indonesia (BEI) periode 2012-2014. 
berikut :

Penarikan sampel dengan teknik purposive sampling didasarkan pada kriteria sebagai

1. Perusahaan manufaktur yang mempublikasikan laporan keuangan selama periode penelitian di Bursa Efek Indonesia.

2. Perusahaan manufaktur yang terdaftar di Bursa Efek Indonesia yang memiliki data laporan keuangan yang lengkap selama periode penelitian.

3. Jumlah perusahaan manufaktur yang menggunakan mata uang rupiah dalam laporan keuangannya

4. Perusahaan manufaktur yang memiliki return saham selama periode penelitian.

\section{Metode Pengambilan Sample}

Pengambilan sample dalam penelitian dilakukan dengan purposive sampling

\section{Jenis dan Pengumpulan Data}

Jenis data dalam penelitian ini adalah data dokumenter, sedangkan sumber data dalam penelitian ini adalah data sekunder. Pengumpulan data -data tersebut diperoleh secara tidak langsung melalui media perantara. Data sekunder yang digunakan dalam penelitian ini adalah laporan tahunan perusahaan (annual report), dan data perusahaan yang diperoleh dari Bursa Efek Indonesia dan Indonesian Capital Market Directory tahun 2012-2014 .

\section{Variabel Penelitian}

1. Variabel dependent (Y)

Variabel dependent yang digunakan dalam penelitian ini adalah return saham

\section{Variabel independent $(\mathrm{X})$}

Variabel bebas (X) dalam penelitian ini adalah laba Kotor (X1), arus kas operasi (X2),

\section{Kerangka Pemikiran Teoritis}

Berdasarkan penjelasan diatas maka dapat dikembangkan kerangka pemikiran teoritis seperti dibawah ini:
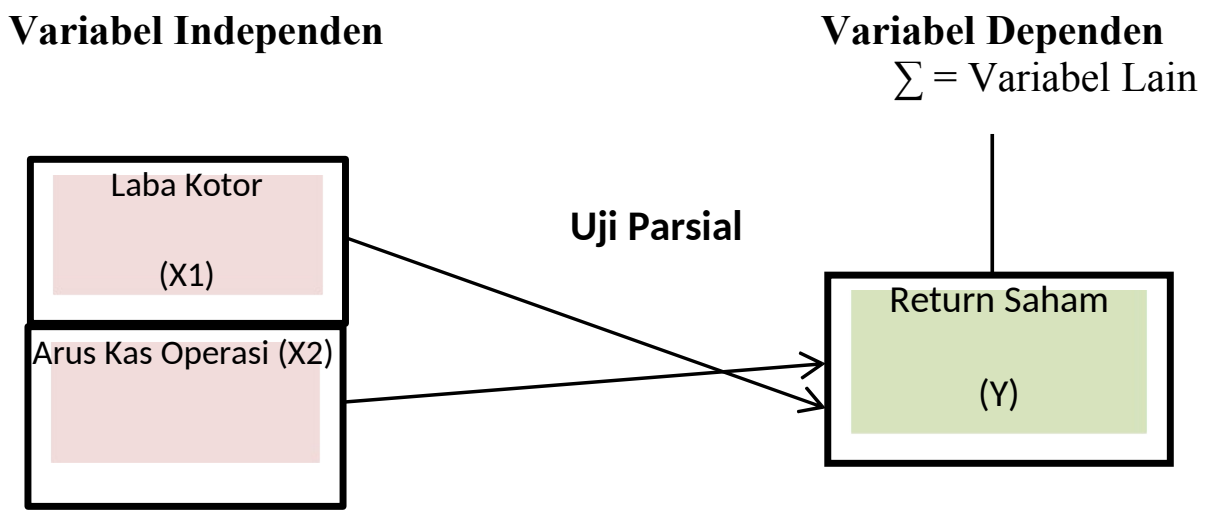

Gambar 3.1

Kerangka Pemikiran 


\section{Hipotesis}

\section{Hipotesis 1:}

H01 : Laba kotor tidak berpengaruh terhadap return saham

Ha1 : Laba kotor berpengaruh terhadap return saham

Hipotesis 2:

H02 : Arus kas operasi tidak berpengaruh terhadap return saham

Ha2 : Arus kas operasi berpengaruh terhadap return saham

\section{Metode Analisis Data}

Metode analisis data yang digunakan dalam penelitian ini adalah analisis deskriptif dan analisis statistik, berikut uraian dari kedua metoda analisis tersebut:

\section{Analisis Deskriptif}

Metode analisis deskriptif merupakan metode yang digunakan untuk menganalisis datadata yang tersedia dan diolah sehingga diperoleh gambaran yang jelas mengenai fakta-fakta fenomena yang diteliti.

Analisis deskriptif ini bertujuan untuk memberikan penjelasan mengenai variable yang digunakan dalam penelitian yang meliputi dependen (Y) yaitu return saham perusahaan manufaktur periode tahun 2012-2014 dan variable independen (X) yang digunakan yaitu laba kotor dan arus kas operasi.

\section{Analisis Statistik}

Kebenaran hipotesis yang diajukan perlu dibuktikan dengan menggunakan uji regresi linier berganda. Beberapa tahapan yang dilakukan sebelum melakukan uji regresi linier berganda diperlukan uji asumsi klasik terlebih dahulu.

\section{Uji Asumsi Klasik}

\section{a. Uji Normalitas}

Uji ini bertujuan untuk menguji apakah data yang digunakan telah terdistribusi normal. Model regresi yang baik adalah yang memiliki data terdistribusi normal. Menguji normalitas data, dapat dilihat pada grafik probability plot. Data dapat dikatakan normal bila data atau titik titik tersebar disekitar garis diagonal dan penyebarannya mengikuti garis diagonalnya. Metode yang lebih akurat untuk menguji normalitas adalah dengan uji Kolmogorov Smirnov, yaitu dengan melihat angka nilai signifikansinya lebih dari 0.05.

\section{b. Uji Multikolonieritas}

Uji multikolonieritas bertujuan untuk menguji apakah model regresi ditemukan adanya korelasi antar variabel bebas. Model regresi yang baik seharusnya tidak terjadi korelasi diantara variabel bebas. Untuk mendeteksi ada atau tidaknya gejala multikolinieritas dalam suatu model regresi dapat diketahui dari Variance Inflation Factor (VIF) apabila nilai VIF kurang dari 10 dan Tolerance lebih dari 0,1 maka dinyatakan tidak terjadi multikolinieritas. 


\section{c. Uji Autokorelasi}

Uji ini bertujuan untuk menguji apakah dalam model regresi linier ada korelasi antara kesalahan pengganggu pada periode $\mathrm{t}$ dengan kesalahan pengganggu pada periode $\mathrm{t}-1$ (sebelumnya). Pengujian ada tidaknya autokorelasi dalam persamaan ini digunakan uji Durbin Watson (DW - test). Model regresi yang baik adalah model yang tidak mengandung autokorelasi. Nilai uji statistik Durbin-Watson harus menunjukkan nilai 1-2 atau tidak boleh lebih dari tiga .

\section{d. Uji Heteroskedastisitas}

Uji heteroskedastisitas bertujuan untuk menguji apakah dalam sebuah model regresi terjadi ketidaksamaan varians dari suatu pengamatan ke pengamatan yang lain. Model regrasi yang baik adalah seharusnya tidak terjadi heteroskedastisitas. Uji heteroskedastisitas bisa dengan melihat pola titik-titik pada grafik regresi. Jika tidak ada pola yang jelas, seperti titik-titik menyebar di atas dan dibawah angka 0 pada sumbu Y, maka tidak terjadi heteroskedastisitas.

\section{Menilai Goodness Of Fit Suatu Model}

\section{Koefisien Determinasi $\left(R^{2}\right)$}

Koefisien determinasi $\left(R^{2}\right)$ bertujuan untuk mengukur seberapa jauh kemampuan model dapat menjelaskan variasi variabel dependen. Nilai koefisien determinasi adalah antara nol dan satu. Nilai $R^{2}$ yang kecil berarti kemampuan variabel-variabel independen dalam menjelaskan variasi variabel dependen yang amat terbatas. Nilai yang mendekati satu berarti variabel-variabel independen memberikan hampir semua informasi yang dibutuhkan untuk memprediksi variasi variabel dependen. Secara umum, koefisien determinasi untuk data silang (crossection) relatif rendah karena adanya variasi yang benar antara masingmasing pengamatan, sedangkan untuk data runtun waktu (times series) biasanya mempunyai nilai koefisien determinasi yang tinggi. Dalam output SPSS, koefisien determinasi terletak pada tabel model summary dan tertulis Adjusted R square. Imam Ghazali (2013:97)

\section{Uji Regresi Linier Berganda}

Metode analisis regresi linear berganda merupakan suatu bentuk hubungan linear antara dua atau lebih variabel independen dengan variabel dependennya. Uji yang dilakukan dalam menganalisis penelitian ini adalah sebagai berikut:

\section{Uji F}

Uji ini merupakan pengujian untuk melihat pengaruh dari variabel-variabel independen secara simultan terhadap variabel dependen. Dalam pengujian ini sebelumnya dirumuskan hipotesisnya.

H0: Variabel-Variabel Independen secara simultan tidak berpengaruh terhadap variabel dependen

H1: Variabel- variabel Independen secara simultan berpengaruh terhadap variabel dependen

Kriteria pengujian untuk uji $\mathrm{F}$ berdasarkan signifikansi sebagai berikut :

Jika Signifikansi $>0,05$ maka H0 diterima

Jika Signifikansi < 0,05 maka H0 ditolak 


\section{Uji t}

Digunakan untuk membuktikan pengaruh variabel independen terhadap variabel dependen secara individu atau parsial. Dalam pengujian ini sebelumnya dirumuskan hipotesisnya.

H0: Variabel Independen tidak berpengaruh terhadap variabel dependen

H1: Variabel Independen berpengaruh terhadap variabel dependen

Kriteria pengujian untuk uji t berdasarkan signifikansi sebagai berikut:

Jika Signifikansi $>0,05$ maka H0 diterima

Jika Signifikansi $<0,05$ maka H0 ditolak

\section{Persamaan Regresi Linier Berganda}

Model persamaan regresi berganda dalam penelitian ini adalah sebagai berikut: $\mathrm{Y}=\mathrm{a}+\mathrm{b} 1 \mathrm{X} 1+\mathrm{b} 1 \mathrm{X} 2+\varepsilon$

$\begin{array}{ll}\text { Keterangan: } & \begin{array}{l}\mathrm{Y}=\text { Variabel terikat (return } \text { saham) } \\ \mathrm{a}\end{array} \\ \beta_{1,2}=\text { Konstanta persamaan regresi } \\ \text { variabel X1 }=\text { Laba kotor } \\ \mathrm{X} 2 \quad=\text { Arus kas dari aktivitas } \\ \text { operasi } \varepsilon \quad=\text { error }\end{array}$

\section{ANALISIS HASIL DAN PEMBAHASAN Analisa Deskriptif}

\begin{tabular}{|l|l|l|l|l|l|}
\hline Descriptive Statistics & $\mathrm{N}$ & $\begin{array}{l}\text { Minimu } \\
\mathrm{m}\end{array}$ & $\begin{array}{l}\text { Maximu } \\
\mathrm{m}\end{array}$ & Mean & $\begin{array}{l}\text { Std. } \\
\text { Deviation }\end{array}$ \\
\hline Laba Kotor (X1) & 35 & 8.35 & 16.05 & 11.8763 & 1.53942 \\
\hline $\begin{array}{l}\text { Arus Kas } \\
\text { Operasi (X2) }\end{array}$ & 35 & 10.06 & 25.94 & 18.6706 & 4.59076 \\
\hline $\begin{array}{l}\text { Return Saham } \\
\text { (Y) }\end{array}$ & 35 & .10 & 1.33 & .6183 & .39410 \\
\hline $\begin{array}{l}\text { Valid N } \\
\text { (listwise) }\end{array}$ & 35 & & & & \\
\hline
\end{tabular}

Sumber: Data diolah dengan SPSS

\section{Analisis Statistik}

Analisis data statistik bertujuan untuk membuktikan kebenaran hipotesis yang diajukan maka digunakan regresi linier berganda. Beberapa tahapan yang digunakan yang digunakan sebelum melakukan uji regresi linier berganda diperlukan uji asumsi klasik terlebih dahulu.

\section{Uji Asumsi Klasik}

\section{Uji Normalitas}

Model regresi yang baik adalah memiliki distribusi data yang normal atau mendekati normal. Untuk menguji apakah distribusi data normal atau tidak. Salah satunya dengan menggunakan analisis grafik normal probability plot of regression standardized residual 
pada gambar 4.1 dan table test of normality pada kolom kolmogrov Smirnov pada table 4.3 berikut:

\section{Uji Asumsi Klasik Kolmogrov - Smirnov Test Of Normality}

\begin{tabular}{|l|l|l|l|}
\hline \multirow{2}{*}{} & \multicolumn{3}{|l|}{ Kolmogorov-Smirnov } \\
\cline { 2 - 4 } & Statistic & Df & Sig. \\
\hline Return saham & .130 & 35 & .146 \\
\hline Laba Kotor & .074 & 35 & $.200^{*}$ \\
\hline $\begin{array}{l}\text { Arus Kas } \\
\text { Operasi }\end{array}$ & .142 & 35 & .073 \\
\hline
\end{tabular}

Sumber: Data diolah dengan SPSS

Berdasarkan table diatas terlihat bahwa nilai kolmogrov smirnov untuk semua variable menunjukkan nilai signifikansinya lebih dari 0.05 . Sehingga dapat dikatakan bahwa model regresi pada penelitian ini memiliki distribusi data yang normal .

Analisis grafik normal probability plot of regression standardized residual dapat dilihat pada gambar 4.1 berikut:

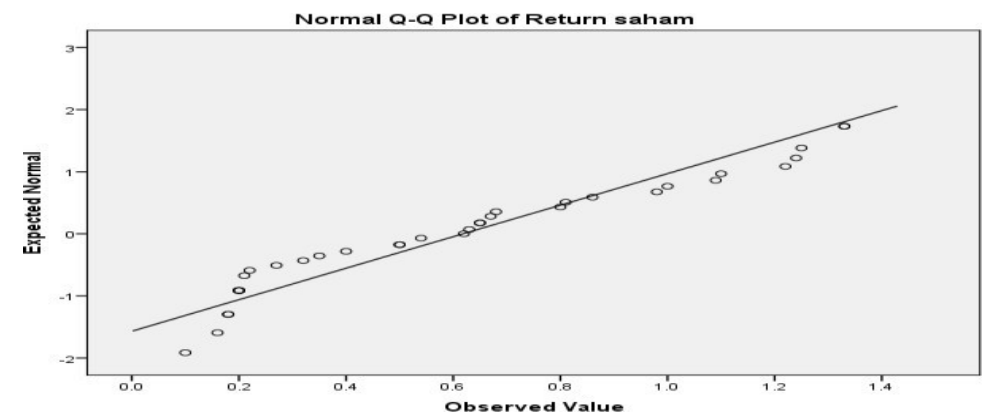

Sumber: Data diolah dengan SPSS

\section{Gambar}

\section{Normal Probability Plot of Regression Standardized Residual}

Gambar diagram Normal P-P Plot regression standardized diatas menunjukkan bahwa keberadaan titik-titik terlihat menyebar disekitar garis serta penyebarannya mengikuti arah garis diagonal namun tidak sejajar dengan garis.

\section{Uji Multikolonieritas}

Model regresi yang baik adalah model regresi yang tidak terjadi korelasi diantara variabel bebas. Dapat diketahui dengan melihat nilai Variance Inflation Factor (VIF) jika VIF kurang dari 10 dan Tolerance lebih dari 0,1 maka dinyatakan tidak terjadi multikolinieritas. 


\section{Uji Multikolinearitas}

\begin{tabular}{|c|c|c|c|c|c|c|c|c|}
\hline \multicolumn{9}{|c|}{ Coefficients $^{\mathrm{a}}$} \\
\hline \multirow{2}{*}{\multicolumn{2}{|c|}{ Model }} & \multicolumn{2}{|c|}{$\begin{array}{l}\text { Unstandardized } \\
\text { Coefficients }\end{array}$} & \multirow{2}{*}{$\begin{array}{l}\text { Standardi } \\
\text { zed } \\
\text { Coefficie } \\
\text { nts } \\
\text { Beta }\end{array}$} & \multirow[t]{2}{*}{$T$} & \multirow[t]{2}{*}{ Sig. } & \multicolumn{2}{|c|}{\begin{tabular}{|l} 
Collinearity \\
Statistics
\end{tabular}} \\
\hline & & B & $\begin{array}{l}\text { Std. } \\
\text { Error }\end{array}$ & & & & \begin{tabular}{|l|}
$\begin{array}{l}\text { Toleranc } \\
\mathrm{e}\end{array}$ \\
\end{tabular} & VIF \\
\hline \multirow{3}{*}{1} & $\begin{array}{l}\text { (Constant } \\
\text { ) }\end{array}$ & 1.606 & .568 & & 2.829 & .008 & & \\
\hline & $\begin{array}{l}\text { Laba } \\
\text { Kotor }\end{array}$ & \begin{tabular}{|l|}
-.049 \\
\end{tabular} & .043 & -.191 & -1.138 & 263 & .998 & 1.002 \\
\hline & $\begin{array}{l}\text { Arus Kas } \\
\text { Operasi }\end{array}$ & -.022 & .014 & -.255 & -1.522 & 138 & \begin{tabular}{|l|}
.998 \\
\end{tabular} & 1.002 \\
\hline
\end{tabular}

Sumber: Data diolah dengan SPSS

Berdasarkan table uji multikolinearitas diatas terlihat bahwa nilai VIF untuk masingmasing variable kurang dari 10 artinya bahwa model regresi penelitian ini bebas dari gejala multikolinearitas atau dapat dikatakan bahwa tidak terjadi korelasi diantara variabel bebas.

\section{Uji Autokolerasi}

Model regresi yang baik adalah model yang tidak mengandung autokorelasi. uji Durbin Watson (DW - test) digunakan untuk menguji autokorelasi. Nilai uji statistik Durbin-Watson harus menunjukkan nilai 1-2 atau tidak boleh lebih dari tiga .

\section{Uji Autokorelasi}

\begin{tabular}{|c|c|c|c|c|c|c|c|c|c|}
\hline \multirow[t]{2}{*}{ Model } & \multirow[t]{2}{*}{$\mathrm{R}$} & \multirow{2}{*}{$\begin{array}{l}\text { R } \\
\text { Squa } \\
\text { re }\end{array}$} & \multirow{2}{*}{$\begin{array}{l}\text { Adjust } \\
\text { ed R } \\
\text { Square }\end{array}$} & \multicolumn{5}{|c|}{ Change Statistics } & \multirow{2}{*}{$\begin{array}{l}\text { Durbin- } \\
\text { Watson }\end{array}$} \\
\hline & & & & \begin{tabular}{|l|}
$\mathrm{R}$ \\
Square \\
Change
\end{tabular} & \begin{tabular}{|l} 
F \\
Chan \\
ge
\end{tabular} & df1 & df2 & $\begin{array}{l}\text { Sig. } \\
\text { F } \\
\text { Chan } \\
\text { ge }\end{array}$ & \\
\hline 1 & $\begin{array}{l}.3 \\
25 \\
\mathrm{a}\end{array}$ & .106 & .050 & .106 & 1.893 & 2 & 32 & .167 & 1.411 \\
\hline
\end{tabular}

a Predictors: (Constant), Arus Kas Operasi, Laba Kotor

b Dependent Variable: Return saham

Sumber: Data diolah dengan SPSS

Berdasarkan tabel uji autokorelasi diatas terlihat bahwa nilai Durbin Watson sebesar 1,411. Ini berarti bahwa model regresi yang digunakan dalam penelitian sudah baik karena nilai Durbin Watson berada diantara nilai 1-2. 


\section{Uji Heteroskedastisitas}

Model regrasi yang baik seharusnya tidak terjadi heteroskedastisitas. Uji heteroskedastisitas bisa dengan melihat pola titik-titik pada grafik regresi. Jika tidak ada pola yang jelas, seperti titik-titik menyebar di atas dan dibawah angka 0 pada sumbu $\mathrm{Y}$, maka tidak terjadi heteroskedastisitas. Berikut grafik yang menunjukkan bahwa model regresi pada penelitian ini bebas dari gangguan heterokedastisitas.

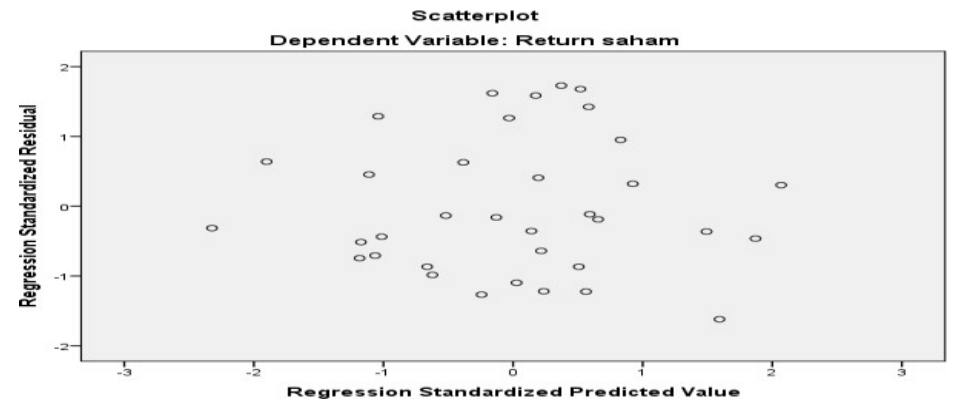

Sumber: Data diolah dengan SPSS

\section{Gambar \\ Uji Heteroskedastisitas \\ Koefisien Determinasi $\left(R^{2}\right)$}

Koefisien determinasi $R^{2}$ bertujuan untuk mengukur seberapa jauh kemampuan model dapat menerangkan variasi variabel.

R-Square pada Model Summary

\begin{tabular}{|l|l|l|l|l|}
\hline Model & $\mathrm{R}$ & $\begin{array}{l}\mathrm{R} \\
\text { Square }\end{array}$ & $\begin{array}{l}\text { Adjusted R } \\
\text { Square }\end{array}$ & $\begin{array}{l}\mathrm{R} \text { Square } \\
\text { Change }\end{array}$ \\
\hline 1 & $.325^{\mathrm{a}}$ & .106 & .050 & .106 \\
\hline
\end{tabular}

Sumber: data diolah dengan SPSS

Dari tabel tersebut dapat terlihat bahwa Adjusted $R^{2}$ memiliki nilai sebesar 0,05 yang mana dapat disimpulkan bahwa model regresi mampu menjelaskan pengaruh variabel laba kotor dan arus kas operasi, terhadap return saham sebesar $5 \%$ sedangkan sisanya 95\% tidak dapat dijelaskan oleh persamaan regresi ini.

\section{Uji Linier Berganda}

\section{Uji Simultan (Uji F)}

ANOVA $^{\mathrm{a}}$

\begin{tabular}{|ll|l|l|l|l|l|l|}
\hline \multicolumn{2}{|l|}{ Model } & $\begin{array}{l}\text { Sum of } \\
\text { Squares }\end{array}$ & Df & $\begin{array}{l}\text { Mean } \\
\text { Square }\end{array}$ & F & Sig. \\
\hline \multirow{2}{*}{1} & Regression & .559 & 2 & .279 & 1.893 & $.167^{\mathrm{b}}$ \\
& Residual & 4.722 & 32 & .148 & & \\
& Total & 5.281 & 34 & & & \\
\hline
\end{tabular}

a. Dependent Variable: Return saham

b. Predictors: (Constant), Arus Kas Operasi, Laba Kotor 
Berdasarkan table diatas terlihat bahwa uji $\mathrm{F}$ ini mempunyai signifikansi sebesar 0,167. Nilai ini menunjukkan bahwa tidak terdapat pengaruh laba kotor, arus kas operasi terhadap return saham pada perusahaan manufaktur di Bursa Efek Indonesia periode 2012-2014.

\section{Uji Parsial (Uji t)}

\section{Coefficients}

\begin{tabular}{|c|c|c|c|c|c|c|}
\hline \multirow{2}{*}{\multicolumn{2}{|c|}{ Model }} & \multicolumn{2}{|c|}{$\begin{array}{l}\text { Unstandardized } \\
\text { Coefficients }\end{array}$} & \multirow{2}{*}{$\begin{array}{l}\text { Standardized } \\
\text { Coefficients } \\
\text { Beta }\end{array}$} & \multirow[t]{2}{*}{$\mathrm{T}$} & \multirow[t]{2}{*}{ Sig. } \\
\hline & & B & Std. Error & & & \\
\hline \multirow{3}{*}{1} & (Constant) & 1.606 & .568 & & 2.829 & .008 \\
\hline & Laba Kotor & \begin{tabular}{|l|}
-.049 \\
\end{tabular} & .043 & -.191 & -1.138 & .263 \\
\hline & $\begin{array}{ll}\text { Arus } & \text { Kas } \\
\text { Operasi } & \end{array}$ & $\mid-.022$ & .014 & -.255 & -1.522 & .138 \\
\hline
\end{tabular}

a. Dependent Variable: Return saham

Berdasarkan hasil pada table coefficients diatas, dapat diketahui hasil uji partial pada penelitian ini:

\section{Laba Kotor}

Hasil pengujian statistik menunjukkan bahwa variable laba kotor mempunyai nilai signifakansi sebesar 0,263 dengan koefisien regresi sebesar -0,49. Hal ini menunjukkan bahwa " tidak ada pengaruh laba kotor terhadap return saham pada perusahaan manufaktur 2012-2014". Hal ini menyatakan bahwa H0 diterima

\section{Arus Kas Operasi}

Hasil pengujian statistik menunjukkan bahwa variable arus kas operasi mempunyai nilai signifakansi sebesar 0,138 dengan koefisien regresi sebesar $-0,222$. Hal ini menunjukkan bahwa " tidak ada pengaruh arus kas operasi terhadap return saham pada perusahaan manufaktur 2012-2014". Hal ini menyatakan bahwa H0 diterima

\section{Persamaan Regresi Linier Berganda}

Dalam penelitian ini digunakan Ln (Logaritma Natural) dikarenakan data antara variable $\mathrm{X}$ dan $\mathrm{Y}$ range datanya terlalu besar sehingga variable $\mathrm{X}$ perlu di Ln kan.

Sehingga rumus regresi berubah menjadi:

$$
\mathrm{Y}=\mathrm{a}+\mathrm{b} 1 \mathrm{LnX} 1+\mathrm{b} 2 \operatorname{LnX} 2+\mathrm{e}
$$

Berdasarkan hasil pada table coefficient dapat disusun persamaan regresi linier berganda sebagai berikut:

$\mathrm{Y}=1,606+(-0.49) \mathrm{X} 1+(-0,22) \mathrm{X} 2$

Keterangan:

$\mathrm{Y} \quad=$ Variabel terikat (return saham)

a $\quad=$ Konstanta persamaan regresi

$\beta_{1,2} \quad=$ Koefsien regresi pada setiap variabel 
$\mathrm{X} 1=$ Laba kotor

$\mathrm{X} 2=$ Arus kas dari aktivitas

operasi $\varepsilon=$ error

Berdasarkan persamaan regresi diatas, maka dapat diinterpretasikan sebagai berikut:

1. Koefisien konstanta sebesar 1,606dengan nilai positif dapat diartikan bahwa return saham akan bernilai 1,606 apabila diasumsikan masing-masing variabel Laba kotor, arus kas operasi diabaikan.

2. Variabel laba kotor memiliki koefisien regresi sebesar - 0.049. Nilai koefisien regresi negatif menunjukkan bahwa laba kotor berhubungan negatif dengan return saham. Hal ini menunjukkan bahwa jika setiap kenaikan satu persen variable laba kotor, dengan asumsi variable lain tetap maka akan menurunkan return saham sebesar 0,049

3. Variabel arus kas memiliki koefisien regresi sebesar - 0,222. Nilai koefisien regresi negatif menunjukkan bahwa laba kotor berhubungan negatif dengan return saham. Hal ini menunjukkan bahwa jika setiap kenaikan satu persen variable arus kas operasi , dengan asumsi variable lain tetap maka akan menurunkan return saham sebesar 0,222

\section{Pembahasan dan Interprestasi \\ Hasil Penelitian Dengan Landasan Teori \\ Laba Kotor Dengan Return Saham}

Hasil pengujian statistik menunjukkan bahwa variabel laba kotor tidak berpengaruh terhadap return saham. Hal ini bertentangan dengan pernyataan yang telah dikemukakan di depan bahwa semakin besar laba kotor yang diperoleh perusahaan maka semakin tinggi minat investor untuk berinvestasi di perusahaan tersebut. Laba kotor menyampaikan sebagian latar belakang tentang bagaimana cara manajemen memenuhi tanggung jawabnya. (Belkouli, 2012:231)

Pengujian statistik menunjukkan bukti empiris bahwa investor beranggapan bahwa biaya barang terjual tidak mampu diprediksi oleh manajer dan tidak dapat berhubungan langsung dengan penciptaan pendapatan, sehingga semakin besar laba kotor tidak dapat meningkatkan nilai expected return saham. Artinya dalam laba kotor para investor belum bisa mengkaitkan antara biaya-biaya yang timbul dengan pendapatan. Fluktuatifnya laba kotor dari tahun ke tahun juga merupakan salah satu faktor bagi investor untuk tidak menjadikan laba kotor sebagai bahan pertimbangan dalam berinvestasi.

\section{Arus Kas Operasi Terhadap Return Saham}

Hasil pengujian statistic menunjukkan bahwa variabel arus kas operasi tidak berpengaruh terhadap return saham. Hal ini bertentangan dengan pernyataan sebelumnya bahwa semakin tinggi arus kas operasional perusahaan maka semakin tinggi pula kepercayaan investor pada perusahaan tersebut, sehingga semakin besar pula nilai expected return saham.

Pengujian statistic menunjukkan bukti empiris bahwa investor tidak tergerak melakukan investasi dengan besaran arus kas operasi. Peningkatan arus kas operasi yang 
menjadi pertanda bahwa perusahaan memiliki kemampuan yang cukup untuk melunasi pinjaman, menjamin kemampuan perusahaan untuk tetap beroperasi, membayar dividen dan melakukan investasi untuk operasi baru juga tidak dilihat oleh investor dalam mengambil keputusan investasinya.

\section{Hasil Penelitian Dengan Penelitian Terdahulu Arus Kas Operasi Terhadap Return Saham}

Hasil pengujian statistik menunjukkan bahwa variabel arus kas operasi tidak berpengaruh terhadap return saham. Hasil penelitian ini konsisten dengan penelitian yang dilakukan oleh Jundan ( 2011), Seno (2011), Meythi (2006)yang menyatakan bahwa arus kas operasi tidak menjamin perusahaan dalam menjalankan aktivitas usahanya dimasa yang akan datang.

Hasil penelitian ini bertentangan dengan penelitian Triyono (1998), Tjiptowati ( 2008 ) yang menyatakan bahwa cash inflows or outflows dari operasi dari periode tertentu akan mempengaruhi harga saham melalui pengaruhnya pada arus kas, sehingga diharapkan komponen arus kas dari operasi mempunyai hubungan yang signifikan dengan return saham. Tidak sejalannya hasil penelitian penulis dengan penelitian yang dilakukan oleh Triyono (1998), Tjiptowati ( 2008) disebabkan karena objek yang diteliti berbeda. Pada penelitian sebelumnya, objek yang diteliti menggunakan perusahaan LQ45 sedangkan penulis menggunakan objek penelitian perusahaan manufaktur yang mempunyai karakteristik yang berbeda dengan perusahaan LQ45.

\section{KESIMPULAN DAN SARAN}

\section{Kesimpulan}

1. Tidak ada pengaruh laba kotor terhadap return saham perusahaan manufaktur yang terdaftar di BEI tahun 2012-2014.

2. Tidak ada pengaruh arus kas operasi terhadap return saham perusahaan manufaktur yang terdaftar di BEI tahun 2012-2014.

\section{Saran}

Penelitian ini mempunyai beberapa kelemahan sehingga penulis mencoba untuk memberikan saran untuk penelitian selanjutnya sebagai berikut:

1. Pengujian yang dilakukan pada tiga periode waktu yang terbatas yaitu periode 2012 sampai dengan 2014. Sehingga hasil penelitian ini tidak dapat digunakan untuk melihat kecenderungan dalam jangka panjang, oleh sebab itu disarankan untuk penelitian selanjutnya dapat dilanjutkan dengan menggunakan periode waktu penelitian yang lebih panjang dan menggunakan jumlah sampel yang lebih variatif dengan jumlah yang lebih banyak sehingga dihasilkan kesimpulan yang valid.

2. Keterbatasan dalam penelitian ini adalah hanya menggunakan 2 variabel independen yaitu laba kotor dan arus kas operasi, terhadap return saham. Oleh sebab itu, untuk penelitian selanjutnya disarankan untuk menambahkan variabel lain yang memungkinkan dapat mempengaruhi return saham seperti harga saham, dividen, ekuitas, masalah ekonomi (seperti inflasi, tingkat suku bunga) serta kondisi politik nasional. 


\section{DAFTAR PUSTAKA}

Belkaouli, Ahmed. 2012. Accounting Theory. Teori Akuntansi. Buku Dua. Jakarta:Salemba Empat

Daniati, Nina dan Suhairi. 2006. Pengaruh Kandungan Informasi Komponen Laporan Arus Kas dan laba bersih terhadap Expected Return Saham. Simposium Nasional Akuntansi (Padang).

Tjiptowati Endang Irianti,2008. Pengaruh kandungan informasi arus kas, komponen arus kas, dan laba akuntansi terhadap harga dan return saham.Thesis_program magister akuntansi. program pasca sarjana universitas Diponegoro.Semarang

Ghazali, Imam, Prof. Dr., H., M.Com., Akt. 2013. Aplikasi Analisis Multivariate dengan Program IBM SPSS 21 Update PLS Regresi. Semarang. Badan Penerbit Universitas Diponegoro.

Hartono, Jogiyanto, Prof. Dr., MBA., Ak. 2003. Teori Portofolio dan Analisis Investasi. Edisi Ketiga. Yokyakarta : BPFE Yokyakarta.

Hardian Hariono Sinaga. 2008. Analisis Pengaruh Total Arus Kas, Laba Akuntansi terhadap Return Saham. Jurnal Ekonomi

Iswandi Sukartaatmadja, 2005. Pengaruh Arus Kas Operasi dan Laba Akuntansi Terhadap Tingkat Keuntungan dan Likuiditas Saham Emiten Sektor Keuangan di Bursa Efek Jakarta., Jurnal Ilmiah Ranggagading, Volume 5/02/2005, STIEKB, Bogor.

Jundan Adiwiratama2011.Pengaruh informasi laba, arus kas, dan ukuran perusahaan terhadap return saham. perusahaan manufaktur yang terdaftar di Bursa Efek Indonesia. Jurnal Ilmiah Akyntansi dan Humanika. Vol 2, No 1.Singaraja

Kieso, Weygandt, Warfield. 2002. Akuntansi Intermediate Edisi Kesepuluh Jilid 1, terjemahan Emil Salim. Jakarta : Erlangga

Meythi, 2006. Pengaruh Arus Kas Operasi Terhadap Harga Saham Dengan Persistensi Laba Sebagai Variabel Intervening, Simposium Nasional Akuntansi 9 (Padang), K-AKPM 01, hal. 1-21.

Pura, Rahman. 2013. Pengantar Akuntansi 1. Jakarta. Erlangga Permana Y, Pengaruh fundamental keuangan, tingkat bunga, dan tingkat inflasi terhadap pergerakan harga saham (Studi kasus perusahaan semen yang terdaftar di BEI). Skripsi. Universitas Gunadarma, Bekasi. 
Petrus,2004 . Pengaruh laba kotor dan arus kas terhadap return saham perusahaan food and beverages yang terdaftar di bursa efek Indonesia. Fakultas Ekonomi, Universitas Gunadarma

Rahmat Febrianto. 2005.Tiga Angka Laba Akuntansi: Mana Yang Lebih Bermakna Bagi Investor? SNA VIII Solo, 15 - 16 September 2005

Reily,Frank K dan Keith C.Brown,2007. Investment Analysis And Portofolio Management. Fifth edition, Dryden Press United State Of America

Satria Pratama dan Dinnul Alfian Akbar, 2013. Pengaruh Laba Akuntansi dan Komponen Arus Kas Terhadap Retun Saham pada Perusahaan Manufaktur yang Terdaftar di Bursa Efek Indonesia, STIE MDP, Palembang.

Sjahrial, Dermawan, Prof. Dr. M.M. 2012. Pengantar Manajemen Keuangan. Edisi 4. Jakarta : Penerbit Mitra Wacana Media.

Sharpe,Willian.F,1991.Investment. second edition, Engewood cliffs, New jersey,Prentice hall International,Inc

Suad Husnan,2001. Dasar-dasar Teori Portfolio dan Analisis Sekuritas. Edisi ketiga, Yogyakarta: UPP Amp YKPN

Seno Jadi Utomo, 2011. Analisis pengaruh arus kas operasi dan laba akuntansi terhadap return saham perusahaan manufaktur di bursa efek Indonesia, universitas negeri Semarang.

Suriani Ginting , 2011. Analisis Pengaruh Pertumbuhan Arus Kas da Laba Akuntansi Terhadap Return Saham pada Perusahaan LQ 45 di Bursa Efek Indonesia, Jurnal Wira Ekonomi Mikroskill, STIE Mikroskil, Medan, Volume1/02/2011.

Skousen, Smith. 2001. Akuntansi Intermediate, Volume Komprehensif, Jilid 2, Edisi Sembilan, Erlangga, Jakarta.

Tjiptowati Endang Iriant. 2008. Pengaruh Kandungan Informasi Arus Kas, Komponen Arus Kas, Dan Laba Akuntansi Terhadap Harga Dan Return Saham. Thesis program studi magister akuntansi. program pasca sarjana.Universitas Diponegoro Semarang

Triyono dan Jogiyanto Hartono. 1998. Hubungan Kandungan Informasi Arus Kas, Komponen Arus Kas dan Laba Akuntansi dengan Harga atau Return Saham. Jurnal Riset Akuntansi Indonesia. Vol. 3. No. 1. Hal : 54-68. 